\title{
REGIONAL DISPARITIES IN THE DISTRIBUTION OF TOURISM TURNOVER IN THE SOUTH-EAST DEVELOPMENT REGION
}

DOI: http://dx.doi.org/10.18509/GBP.2019.51

UDC: 352.071.2:338.48 (4-12)

\author{
Jioță Oana-Elena ${ }^{1,2}$ \\ Pintilii Radu-Daniel ${ }^{1,2}$ \\ Grecu Alexandra ${ }^{1,2}$ \\ Predescu Alisa ${ }^{1,2}$ \\ Drăghici Cristian Constantin ${ }^{1,2}$ \\ ${ }^{1}$ Research Center for Integrated Analysis and Territorial Management, \\ University of Bucharest, Romania \\ ${ }^{2}$ Faculty of Geography, University of Bucharest, Bucharest, Romania
}

\begin{abstract}
In the current national and European framework, concerns have been intensified regarding the analysis of territorial disparities in a more comprehensive, multidimensional vision. In this respect, the study of the way in which tourism turnover is distributed at territorial level may be a way of providing us economic performance indices of the analyzed territorial systems. In this study we propose the analysis of the territorial distribution of tourism turnover within the South-East Development Region and to identify its importance in the development of local economies. Thus, a tourism from turnover database was made for each territorial administrative unit from the South East Development Region, for the period 2000-2016. This database was used for GIS representation of turnover distribution at the territorial administrative unit level, both in terms of evolution and in territorial aspect. As a result of the applied methodology, regional disparities were revealed in the distribution of tourism turnover but also how territorial systems have responded economically to structural shocks.
\end{abstract}

Keywords: territorial disparities, turnover, tourism, South East Development Region, local economy

\section{INTRODUCTION}

Turnover is one of the most important economic indicators in quantifying the economic performance of a company, the same situation being in the case of tourism activities, its size offering indices regarding the economic efficiency of the tourist company. Today, tourism is seen as an economic activity that can stimulate the development of local economies as a way to increase their competitiveness at local, regional or national level [1], [2], [3], [4]. Globally, the total tourism contribution to GDP was USD 7613.3 billion (10.2\% of GDP), the growth rate being projected to reach $3.6 \%$ per year by 2027 , which is slightly more higher than the growth rate of the global economy (3\%) [5]. At the level of Romania, the contribution of tourism to GDP was around 5\% in 2017, the estimates being growth for the next period [6]. Against this background, it becomes clear that an effective economic growth strategy must include the measure to stimulate the development of this economic sector, especially as it can help mitigate territorial disparities [3]. Therefore, the issue of territorial disparities is an important concern at EU level if we think of the concept of territorial cohesion promoted at the level of the 
organization regarding the integrated territorial development [7], [8], [9], [10]. In this respect, the analysis of regional disparities in the distribution of tourism turnover can give us important insights into how this economic sector can influence the level of income in the territorial systems with capitalized resources.

\section{METHODOLOGY}

In the present study we intend to analyze the distribution of tourism turnover in the South East Development Region (Fig. 1). The South-East Development Region overlaps in six counties: Buzau, Vrancea, Galati, Brăila, Tulcea and Constanţa, being the development region with the most diversified tourism resources both natural and anthropic. Also some of these tourist resources are specific, such as the Danube Delta and the Black Sea coast, making this region one of the most attractive for tourism.

In order to analyze the way of distribution of tourism turnover at the regional level, a database was created for each administrative-territorial unit, a database used to produce cartographic materials for the distribution of turnover, following both the evolution and the distribution at the territorial level.

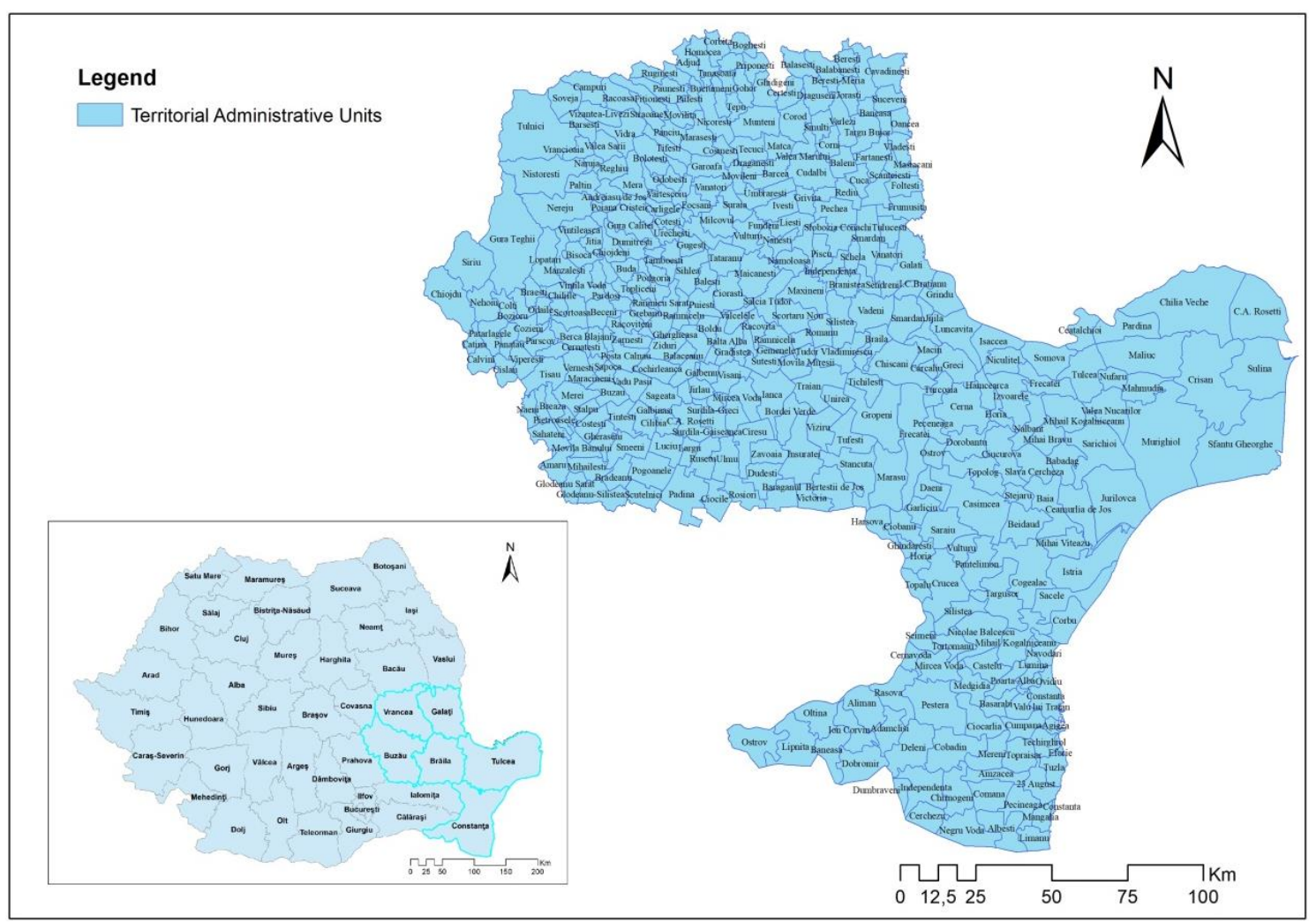

Figure 1. South-East Development Region

\section{RESULTS}

For the year 2000 (fig. 2), the highest values of the turnover were recorded in Constanta (52722695 Ron) and Mangalia (39567176 ron), followed by Galati, Buzau, Tulcea, Focsani, Braila, with turnover values of less than 15000000 Ron. However, it is noted that $72 \%$ of the territorial administrative units did not register tourism turnover, which shows that this economic activity was still incipient. Also, a number of localities such as 
Eforie (CT), Merei (BZ), Stejaru (TL), Crişan (TL) have turnover values between 500,000 and 400,000 Ron.

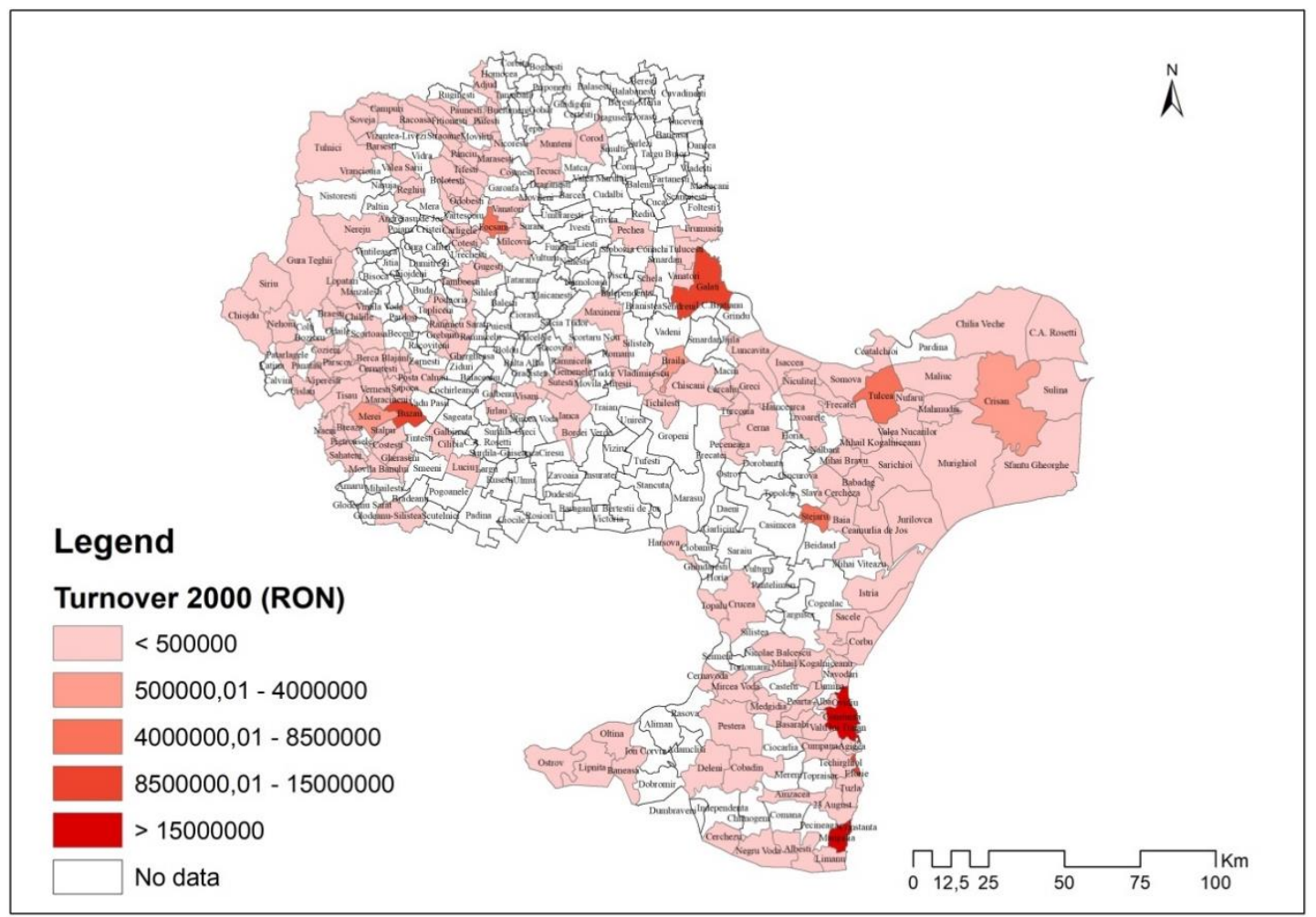

Figure 2. Distribution of turnover from tourism at the level of the South-East Development Region in 2000

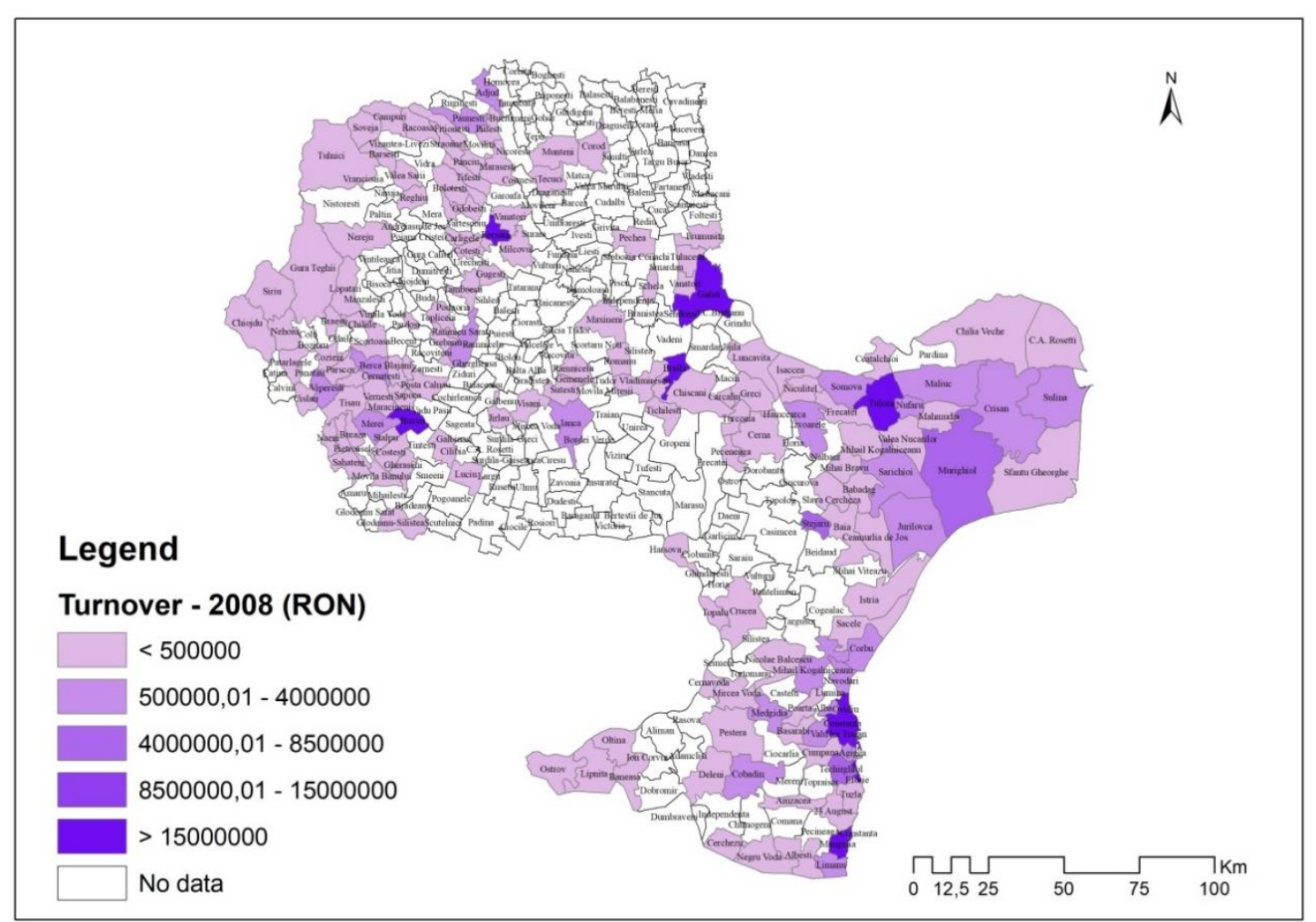

Figure 3. Distribution of turnover from tourism at the level of the South-East Development Region in 2008 


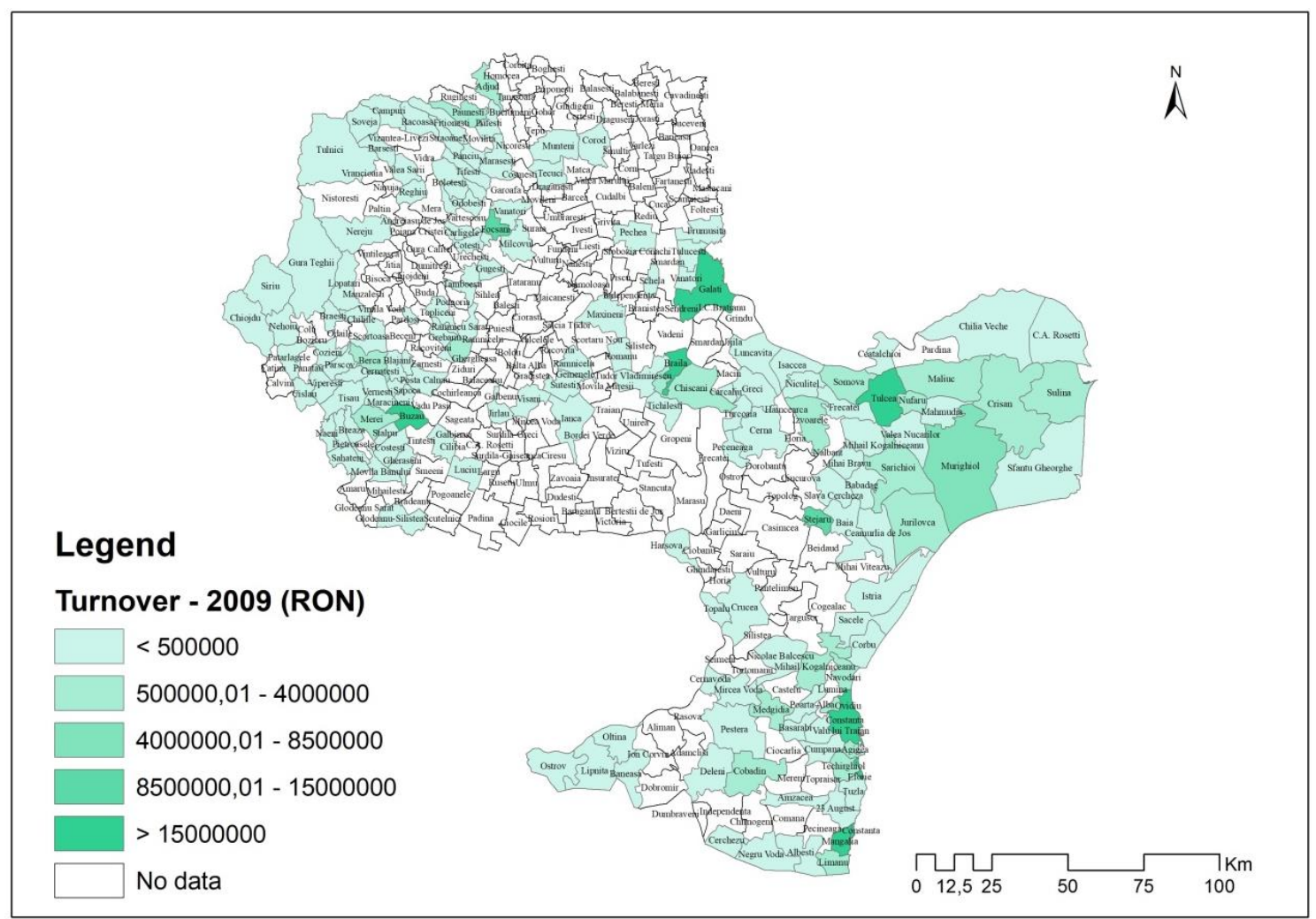

Figure 4. Distribution of turnover from tourism at the level of the South-East Development Region in 2009

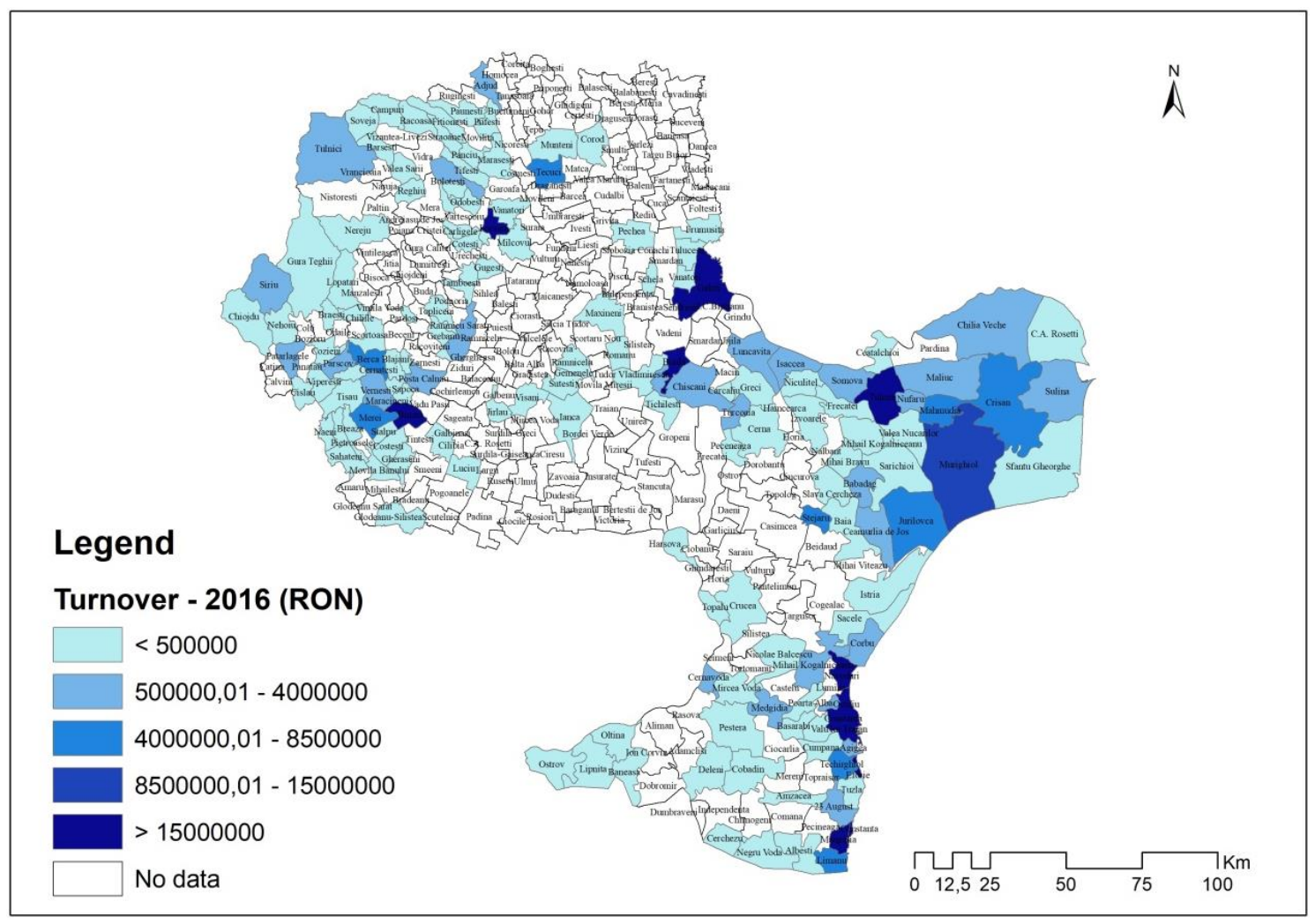

Figure 5. Distribution of turnover from tourism at the level of the South-East Development Region in 2016 
The situation in the year 2008 (fig. 3) is radically changed compared to the year 2000, the share of the localities that did not register tourism turnover reduced to $41 \%$. Also, all the county residences exceed the threshold of 15000000 Ron the maximum value being registered in the Constanta municipality (282421659 Ron, a six times increase in the Turnover), Mangalia (131063016 Ron) with an increase of 3 times more). Also at the county level, Constanta (Corbu, Năvodari, Medgidia, Cobadin, Techirghiol, etc.) and Tulcea (Murighiol, Maliuc, Sulina, etc.) are the counties with the highest number of territorial administrative units with high values from tourism.

At the level of 2009 (Fig. 4), the tourism turnover in the entire region registered a decrease of about $18 \%$ due to the economic crisis, the county's municipalities remaining above the 150000 Ron threshold, with the exception of Focsani which drops from the value of 9565435 ron from 17653534 Ron in 2008.

For the year 2016 the total turnover (fig. 5) from tourism sector, of the region, registered the highest value in the four years under review, being 35\% higher than in 2008, although in 2009 it registered a slight decrease. Analyzing the distribution of turnover in 2016, it is first of all noted the increase in disparities between the territorial administrative units with important tourism resources, which have been capitalized higher (administrative units in the Danube Delta and the Black Sea coast) and territorial administrative units that do not have such resources or are poorly capitalized (territorial administrative units in the southern area of Braila county or northern Galati county).

\section{CONCLUSIONS}

The analysis of the distribution of turnover in the South-East Development Region, during the period 2000-2016, highlights the following:

- Territorial administrative units with turnover from tourism activities are concentrated in Tulcea County (Danube Valley and Danube Delta), Constanța (coastal area, Constanța and Mangalia ports, Danube-Black Sea Canal), Buzău and Vrancea (subCarpathian and mountain areas ) but also along the main road arteries that cross the region (E85, E60, E87, E70);

- There are also differences between the counties with rich tourist resources (coastal, delta, mud volcanoes) and those with predominant activities of agriculture and industry;

- As regards the territorial distribution of turnover values over the analyzed period, there is an increase in the disparities between the territorial administrative units and those with tourism resources having a turnover which shows a growth trend for the analyzed period.

- the analysis of regional disparities in the distribution of turnover, indicates that tourism can significantly contribute to the reduction of territorial economic disparities. The turnover generated by tourism activities, but especially its size, can be a good indicator of the economic performance in the ansamble and in particular of the tourism in the territorial systems that have specific resources. Therefore, a solution for the efficiency of the economic activity at the level of the territorial systems is the elaboration of efficient management plans through which the local resources (implicitly the tourist ones) are valorised at the highest level so that the result is a reduction of the disparities at the local level, regional or national level. This can only be achieved through a detailed knowledge of local economic components and how they interact with each other, but also with other components of the regional and national economic system [11], [12], [13] , [14]. 


\section{REFERENCES}

[1] Strat V.A., Davidescu A.A.M, Grosu R.M \& Zgură I.D. A Quantitative Approach Regarding the Evolution of the Romanian Tourism Firms, During and After the Global Financial Crisis, Amfiteatru Economic, vol. 18, pp 815-828, 2016.

[2] Proença S. \& Soukiazis E. Tourism as an Economic Growth Factor: A Case Study for Southern European Countries, Tourism Economics, vol. 14, pp 791-806, 2008.

[3] Hengyun L., Jason L.C., Gang L. \& Carey G. Tourism and regional income inequality: Evidence from China, Annals of Tourism Research, vol. 58, pp 81-99, 2016.

[4] Barbu C. \& Stănilă A. Economic impact of accommodation structures on the local territorial system, Annals of Valahia University of Targoviste, Geographical Series, vol.16, pp 102-107, 2016.

[5] World Travel \& Tourism Council, Travel \& Tourism Economic Impact, Issues 2017, WTTC, London, 2017.

[6] World Travel \& Tourism Council, Travel \& Tourism Power and Performance Report September 2018, WTTC, 2018.

[7] Zaman G., Goschin Z. \& Vasile V. Evoluția teritorială a dezechilibrelor din România în contextul crizei economice, Revista Română de Economie, Institutul de Economie Națională, vol. 37, pp 20-39, 2013.

[8] Nahtigal M. European Regional Disparities: The Crucial Source of European unsustainability, Lex Localis - Journal of Local Self-Government, vol. 11, pp 601-614, 2013.

[9] Amendola A., Caroleo F.E. \& Coppola G. Regional Disparities in Europe. In: Caroleo F.E., Destefanis S. (eds) The European Labour Market. AIEL Series in Labour Economics. PhysicaVerlag HD, 2006.

[10] Korres G.M. The Role of Innovation Activities in Tourism and Regional Growth in Europe, TOURISMOS: An International Multidisciplinary Refereed Journal of Tourism, vol. 3, pp. 135152, 2007.

[11] Peptenatu D., Drăghici C., Stoian D., Pintilii R. D., Cercleux A. L., Merciu C. \& Schvab A. Qualitative changes in the entrepreneurial sector in emerging territorial systems - Craiova case study, Acta Geographica Slovenica-Geografski Zbornik, vol. 54, pp 293-304, 2014.

[12] Schvab A., Pintilii R. D., Peptenatu D. \& Stoian D. Spatial profile of poverty. Case study: the North-Eastern development region in Romania, Transylvanian Review of Administrative Sciences, vol. 45, pp 201-2016, 2015.

[13] Prăvălie R., Patriche C. V., Sîrodoev I., Bandoc G., Dumitrașcu M. \& Peptenatu D. Water deficit and corn productivity during the post-socialist period. Case study: Southern Oltenia drylands, Romania, Arid Land Research and Management, vol. 30, pp 239-257, 2016.

[14] Pintilii R. D., Andronache I., Diaconu D. C., Dobrea R. C., Zelenakova M., Fensholt R., Peptenatu D., Draghici C. C. \& Ciobotaru A. M. Using Fractal Analysis in Modeling the Dynamics of Forest Areas and Economic Impact Assessment: Maramures County, Romania, as a Case Study, Forests, vol. 8, 2017. 